\title{
THE EFFECT OF KINESIO TAPING ON PAIN AND HAND FUNCTION IN LAUNDRY WORKERS WITHCARPAL TUNNEL SYNDROME
}

\author{
Agus Widodo, Septia Novilia, Farid Rahman, Wijianto
}

Study Program of Physiotherapy, Universitas Muhammadiyah, Surakarta

\begin{abstract}
Background: One of theinformal employments is a laundry worker. Laundry workers use both hands repeatedly that can increase the risk of the wrist disorder, which is medically called Carpal Tunnel Syndrome (CTS). CTS is a wrist disorder caused by median nerve suppression that affects movement and functional impairment of the hands in the form of signs and symptoms of pain, tingling and decreasing of hand function. The kinesio taping method is a definitive rehabilitative taping technique that is designed to facilitate the body's natural healing process while providing support and stability to muscles and joints without restricting the body's range of motion as well as providing extended soft tissue manipulation to prolong the benefits of manual therapy administered within the clinical setting. This study aimed to determine the effect of giving kinesio taping on pain and hand function of laundry workers.
\end{abstract}

Subjects and Method: This was a quasi experiment with pre and post test design with control group. Asample of 18 laundry workers with CTS was divided into two groups, consisting of treatment and control groups. The dependent variables were pain and hand function. The independent variable was kinesio taping. The kinesio taping was implemented for 5 days with 2 day breakand lasted for 3 weeks. Pain was measured by visual analogue scale (VAS). Hand function was measured by Boston Carpal Tunnel Questionnaire. The data were analyzed by Wilcoxon test and Mann Whitney.

Results: After kinesio taping, the pain scores in the experimental group were 1.35 for still pain, 1.28 for pressure pain, and 1.57 for moving pain, respectively, while the pain scores in the control group 3.45 for still pain, 2.88 for the pressure pain, and 3.05 for the moving pain, with $\mathrm{p}=0.027$. The hand function scores in the experimental group was 0.42 , while in the control group was -0.04 with $p=$ 0.034.

Conclusion: Kinesio taping is effective to reduce pain and to improve hand function in patients with Carpal Tunnel Syndrome.

Keywords: Carpal Tunnel Syndrome, pain, hand function, kinesio taping, laundry workers

\section{Correspondence:}

Agus Widodo. Study Program of Physiotherapy, Muhammadiyah University

Surakarta, Surakarta, Central Java. Email: Agus Widodo Email: aw290@ums.ac.id. 